10.53116/pgaflr.2017.1.3

\title{
The Fundamentals of Monetary Fulfilment in Tax Administration
}

\author{
Adrián Popovič ${ }^{*}$ \\ * JUDr. Adrián Popovič is an internal PhD student at the Department of Financial Law, Tax Law and \\ Economy at the Faculty of Law, Pavol Jozef Šafarik University in Košice. (e-mail: adrian.popovic@ \\ student.upjs.sk)
}

\begin{abstract}
In this article, the author discusses a brief definition of principles and fundamentals from a theoretical and legal point of view. Based on this division, the author characterizes and mentions principles and fundamentals that are applicable in a tax administration. The paper differentiates between the basic fundamentals of tax administration and the further fundamentals of tax administration. In this respect the author draws attention to the unnamed further fundamentals of tax administration which, until now, were not named by the theory of law. In the article the author mentions these fundamentals, analyses them and finds their application in tax administration. In particular, the author refers to the fundamentals of monetary fulfilment in tax administration, the definition of which can serve the better understanding of the nature of tax evasions and the improvement of the combat against them.
\end{abstract}

Keywords: fundamentals; principles of tax administration; monetary purpose of taxes

\section{Introduction}

One of the basic tasks of the state is undoubtedly the collectivization of funds and their concentration in the state budget and other public budgets. Generally, taxes are the most important forms of these funds and belong to the most important revenues of the state and other public bodies. Their strict observance and application is also a guarantee of a smooth implementation of tax administration and limitation of tax evasions. For this reason, it is necessary to pay attention to the examination of tax administration and to its individual principles and fundamentals, whose application in the implementation of tax administration ultimately determines its character.

It cannot be overlooked that the consistent differentiation of principles and fundamentals of tax administration has its own justification and they form a comprehensive complex together that can legitimately achieve the filling of public budgets while the basic rights of obligated persons are respected. This system of principles and fundamentals of tax administration forms a set of general rules in which the rights and obligations of the subjects of tax legislative relations in the implementation of tax administration are specified. Within the realization of tax administration it is necessary to intervene in the ownership of obliged person, ${ }^{2}$ in order to achieve the monetary income. Therefore, it is important to preserve the applicability of the principles and fundamentals of tax administration as more general rules of conduct. On the other hand, the fiscal interest of the state and other bodies governed by public law is prioritized when implementing tax administration. 
The fulfilment of tax administration in the Slovak Republic is characterized and limited by principles and fundamentals which are established in the Tax Procedure Code. ${ }^{3}$ These principles and fundamentals interact with principles and fundamentals of the so called good governance and with principles and fundamentals which result only indirectly from the Tax Procedure Code and from special legislations applicable within the realization of tax administration.

\section{Principles and Fundamentals from the Theory of Law}

At the beginning of this subchapter, it should be noted that the distinction between principle and fundamentals is mainly a local, i.e. Slovak and Czech phenomena. ${ }^{4}$ There is no such distinction in foreign terminology and in most foreign legal systems only one of these two terms is used to express their content. ${ }^{5}$

The concept of a principle comes from a Latin word "principium", which literally expresses a basis, a beginning, origin, source or base. ${ }^{6}$ Although the modern literature of the theory of law deemed to correspond to the term fundamentals, it should be noted that in this sense a principle is understood as an original rule which constitutes a basis for other rules. ${ }^{7}$ The principle can, therefore, be characterized generally as the fundamental and leading idea, which is valid without residue, which does not allow any exception and, for this reason, has an absolute determination. In short, the principle can be defined as a certain absolute value that appears in the human society as normal, automatic, natural or still present. ${ }^{8}$

The fundamentals develop, elaborate and specify the principle in a certain way. By the realization of the fundamentals in real situations, the content of an individual principle is fulfilled. The fundamentals are defined by a normative, more specific and more concrete content; however, it still has a considerably high level of abstraction. In the case of legal fundamentals it should be noted that they are a relatively general rule of law which is aimed in a specific branch of law. On the other hand, the legal principle, in the broadest sense of the word, constitutes an absolutely general rule which is applied without exception and is irrevocable. 9 Since the fundamentals elaborate and specify the principle in some way, it is possible to agree with opinions of members of the scientific community, who characterize the fundamentals in their procedural sense in particular. ${ }^{10}$ It is important not to neglect the fact that the fundamentals, in contrast to the principle, allow the exception of their application, which means that their implementation in certain legal situations is omitted and for a particular case is not taken into account. ${ }^{11}$

The fundamentals are therefore the rule by which it is possible to set the boundaries, within which the rights are realised and the duties are enforced resulting for the subjects of the legal relations from a precept of law in individual branches of law. They constitute a guiding rule for these entities and by observing this rule the intended purpose of the legal process is fulfilled in accordance with the applicable legal principles of the legally consistent state of the democratic establishment as the bearer of the highest possible values of contemporary society. 


\section{Principles and Fundamentals of Tax Administration ${ }^{12}$}

In the current legislation we do not find any mention about the principles of tax administration. $\$ 3$ of the Tax Procedure Code sets out only the "Basic Principles of Tax Administration". However, on the basis of the initial theoretical and legal definition of the problem of principles and fundamentals and on the basis of the nature of the principles defined in the Tax Procedure Code, it is not possible to agree with the inclusion of these principles among the fundamentals. In this context, it is possible to identify the following principles of tax administration that have been reflected in tax legislation:

- the principle of legality and the principle of legal protection, ${ }^{13}$

- the principle of uniformity of process decision making of a competent authority in tax administration. ${ }^{14}$

The fundamentals of tax administration ${ }^{15}$ can be characterized as the rules under which tax administrators and persons participating in the tax administration are required to proceed and these rules have significant impact on the correct tax enquiry and securing of tax settlement. In $₫ 3$ of the Tax Procedure Code the basic fundamentals of tax administration are directly embedded and expressis verbis stated but besides these fundamentals it is possible to infer the existence of further fundamentals of tax administration by interpretation from the text of the Tax Procedure Code and special tax legislations. Consequently, it is possible to divide the fundamentals of tax administration into:

1. the basic fundamentals of tax administration, namely:

a. the fundamentals of close cooperation between the tax administrator, taxable entities and other persons and the instructional fundamentals;

b. the fundamentals of speed, the fundamentals of economy (of process economics) and the fundamentals of proportionality;

c. the fundamentals of the free evaluation of evidence;

d. the non-public fundamentals, the fundamentals of tax secrecy and the fundamentals of the protection of personal data;

e. the fundamentals of officiality and the fundamentals of disposition;

f. the fundamentals of informality and the fundamentals of the prohibition of purposeful abuse of rights; ${ }^{16}$

g. the fundamentals of the same procedural status of tax entities;

h. the fundamentals of unified procedure of the tax administrator in deciding factually identical cases (the fundamentals of legitimate expectation).

2. the further fundamentals of tax administration to which belong:

a. the fundamentals of time-barred effect of passage of time; $;^{17}$

b. the fundamentals of monetary fulfilment;

c. the fundamentals of non-retroactivity;

d. the fundamentals of material (objective) truth;

e. the fundamentals of two-stage procedure;

f. the fundamentals of process in a written form and the fundamentals of the use of a state language. 


\section{The Fundamentals of Monetary Fulfilment in Tax Administration}

In the context of the in-depth examination of the issue of the form of fulfilment of a tax and a fee we can point at the fundamentals applied within the realization of tax administration which has been nameless up to now. In particular, it is the fundamentals of monetary fulfilment in tax administration. For the purpose of their content definition, it can be concluded that these fundamentals are characterized by the fade-over of the procedural legislation of tax administration with its substantive legislation.

In order to characterise the fundamentals of monetary fulfilment in tax administration it is necessary to point out the theoretical legal definition of the tax and the fee. The tax can be generally characterized as a monetary fulfilment which has a non-refundable and non-equivalent character, is established by law or in pursuance of the law in order to reimburse national or other public needs, and is generally paid in a pre-determined amount and maturity period..$^{18}$ On the contrary, it is possible to theoretically define the fee as the monetary fulfilment which is constituted by law or in pursuance of the law that is collected for a particular activity by the state or other public entities performed from the initiative or in the interest of the payer in a predetermined maturity period and in most cases in a predetermined amount. Therefore, it is a monetary payment which is of (partially) equivalent character. ${ }^{19}$ It may be summarized that despite the differences of these two types of fulfilments, it is always the fulfilment with the monetary character.

To confirm this we can present the ruling of the Supreme Court of the Slovak Republic, ${ }^{20}$ in which it is pointed out that we consider the tax as a payment for the benefit of the state under the law without the guaranty that the state grants any equivalent to the taxable entities for this payment. On the basis of the analysis of the word "payment" used in the ruling in question, it can be concluded that it is only one way in understanding it in modern economy, so it is the monetary payment, respectively the payment realized through money.

In the historical context, it can be noted that the tax liability could also be fulfilled by natural fulfilment, respectively in the form of special services. However, this is no longer the case because the fulfilment of the tax liability, if any, is required in the form of money. In the light of the above mentioned, it is possible to reflect on how these fundamentals will be followed, for example, if the taxable entity will not have enough money to pay the tax. For this case, $\$ 98$ (1) of the Tax Procedure Code allows the tax administrator to obtain unpaid taxes within the realization of the tax enforcement procedure, in which he can perform tax enforcement by wage deductions and deductions from other incomes, attachment of the claim, the sale of movable objects, withdrawing cash and other things which are not sold, the sale of securities, the sale of a real estate, the sale of an enterprise or parts of it, attachment of the ownership rights related to the business share of a partner in a business company. By these methods of tax enforcement fulfilment the tax administrator is entitled to achieve the monetary fulfilment of an own tax liability of taxable entity.

The status of money within the realization of tax administration is also emphasized when the height of the own tax liability of taxable entity is determined. In this context, the attention can be drawn, for example, to determining the income of taxable entity, which has a non-monetary nature and subject to taxation. In order to determine the own tax 
liability of taxable entity, the non-monetary income which is not legally tax-exempted must be valued at the usual price at the place and time of the fulfilment, according to its type and quality or its condition and rate of wear, and then it is necessary to add the monetary income. From the point of view of determining the tax base, income is not just the monetary income, but also the non-monetary income, which has to be valued in money. ${ }^{21}$

These fundamentals could be applied also to the implementation of the fiscal function of tax law as one of the most important functions of this legal sector. The meaning of the fiscal function of tax law is to ensure sufficient satisfaction of the fiscal interests of the state, respectively of the territorial self-government. This could be achieved by obtaining enough money, which as such is the revenue of public budgets, be it the state budget or the municipality budget. After obtaining sufficient funds, the fiscal function of tax law can be fully realized, regarding the implementation of the public expenditure budget in particular. The above mentioned statement means, that in order for the fiscal function of tax law to be able to manifest at all, the fundamentals of monetary fulfilment must also influence the concrete tax-law relations. This co-operation of the fundamentals will ensure that money inflows into the public budgets are secured and guaranteed.

If the monetary fulfilment plays such an important role in fulfilling the obligations of a taxable entity, why is this rule not a principle of monetary fulfilment? This question can be answered simply. Both the own tax liability and the monetary fulfilment entitlement, which fulfilment is conditional by the payment in the form of money, constitute only one part of the system of authorizations and obligations, the fulfilment of which is not obligatory in the form of monetary fulfilment. In this context, it may be noted that the following authorizations and obligations are the object of tax law:

1. own tax liability - it is the obligation of a taxable entity, which is expressed by the monetary payment. This obligation is fulfilled at the moment of the transfer of funds from the private-law sphere to the public-law sphere without providing an adequate consideration, respectively services. Even in this case, however, the fundamentals of monetary fulfilment do not always apply, because the tax liability could be equal to zero, respectively the taxable entity may report a tax loss and fulfil his obligation even if he does not pay any money to the tax administrator;

2. other obligations - in this case, different non-monetary obligations exist, both on the part of the taxable entity and on the part of the tax administrator or other persons involved in the tax administration. These include, for example, the duty of the taxable entity to cooperate closely with the tax administrator in tax administration, the obligation to file a tax return and so on. On the other hand, the tax administrator has the obligation to initiate tax proceedings also on his own initiative if there are fulfilled legal conditions for the creation or existence of a tax claim, etc.;

3. authorization for monetary fulfilment - for instance, the taxable entity is entitled to a tax refund or return of tax overpayment and, for example, the tax administrator is entitled to charge the tax by using tools or a right to recover tax arrears;

4. authorization of non-monetary nature - for instance, on the side of the taxable entity it is the right to represent and be represented in the tax administration, the right to appeal and so on. In the case of the tax administrator, there is the right 
to carry out a tax audit and a local enquiry, the right to extend the time limit and to forgive a delay, etc. ${ }^{22}$

On the basis of the above mentioned, it can be stated that the fundamentals of monetary fulfilment should be included among the further fundamentals of tax administration. Although the form of natural fulfilment, respectively the form of performance of specific services is not possible as the method of payment of the tax or the fee under the current legislation, the fulfilment of the obligation of a monetary nature has to be seen in the broader context of the system of authorizations and obligations existing in the tax administration, which create the content of the object of tax law itself. In this sense, the fundamentals of monetary fulfilment acts within the realisation of tax administration.

\section{Conclusion}

In the Slovak legislation, the Slovak legislator omitted to establish certain fundamentals, the existence and applicability of which have a significant impact on the lawfulness of tax administration in its broadest sense. Their importance is notable even though they stem from the Tax Procedure Code only indirectly. It can be assumed that the pronouncement of the provisions of individual fundamentals would have a positive effect, in particular, on simplifying the interpretation of tax legislation, which would have an undoubtedly positive influence on the tax discipline of the taxable entity. Therefore, the legislature should, in the future, strive for a possible legal enshrinement of the fundamentals of tax administration, the existence of which is not explicitly laid down in the Tax Procedure Code, but are applied within the realization and implementation of the tax administration.

This article pointed at the existence of the unnamed fundamentals of tax administration until now, namely the fundamentals of monetary fulfilment in tax administration. In this context, it should be noted that not even scientists of tax law can ignore this issue and treat it as closed. As the tax administration changes, the applicability of its individual fundamentals changes too. These aspects have to be continuously examined, it is needed to specify their content and update the scope and conditions of the application of each of the fundamentals. For this reason, the role and work of individual authors of tax-law science is getting more important.

The principles and fundamentals of tax administration should be the guiding line not only for authorized entities in tax relations but also for compulsory subjects. It may be presumed that if the existence of these principles and fundamentals were avoided, on the one hand, the tax administrator would slip into undesirable need to act against the taxable entity, and on the other hand, the taxable entity would not know how to defend himself against such a conduct, which breaches the law. Respecting the principles and fundamentals of tax administration creates a guarantee for the protection of a liable person and the entitled person which can be invoked in the absence of legal proceedings of any of the subjects of tax relations. At the same time, it cannot be forgotten that they serve all the entities of these relationships as a material correction by which they assess their further actions in the application and fulfilment of their rights and duties under the tax law. 


\section{References}

1. This article represents a partial output of the grant project VEGA no. 1/0846/17 "Implementation of the initiatives of the EU institutions in the field of direct taxes and indirect taxes and their budgetary law implications" and VVGS no. 2016-284 "EU initiatives to prevent tax evasions and their implementation into national law".

2. See also František Bonk, Fiskálny záujem štátu verzus dĺžka trvania daňovej kontroly [Fiscal Interest of the State Versus Duration of Tax Control], 40-52, in Dny práva 2015 - Days of Law 2015: V. čast: Dobled, dozor, kontrola ve veréejné finančni cinnosti [V. Part: Supervision, Verification, Control of Public Financial Activities], (Brno, Masarykova Univerzita, 2016), and also Ivana Štieberová, Selected Aspects of Local Enquiry in the Slovak Republic, 451-463, in Tax Codes Concepts in the Countries of Central and Eastern Europe (Bialystok, Temida 2, 2016).

3. The basic legislation which regulates tax administration in the Slovak Republic is the Act no. 563/2009 Coll. on Tax Administration (Tax Procedure Code) and on amendments and supplements to certain laws in the wording of later regulations. Hereinafter as "Tax Procedure Code".

4. Vladimír Babčák, as the principal representative of the School of Tax Law in Košice introduces the idea of division of the principles and fundamentals in tax administration in his research works. For more details see Vladimír Babčák, Daňové právo na Slovensku [Tax Law in Slovakia], 422-447, (Bratislava, EPOS, 2015).

5. Tomáš Mészáros, Kukučie vajcia...alebo zásady, ktoré nie sú princípmi [Cuckoo’s Eggs...or Principles that Are Not Principles], 533, in Základné zásady v rozhodovacej činnosti súdnej moci: Zbornik vedeckých prác doktorandov [Basic Principles in the Judicial Activity: Proceedings of Doctoral Students] (Košice, Univerzita Pavla Jozefa Šafárika v Košiciach, 2014).

6. Petr Čechák, Principy jako řídící ideje právní regulace [Principles as Leading Ideas of Legal Regulation], 13, in Principy a zásady v právu - teorie a praxe. Sbornik z konference Olomoucké debaty mladých právníki̊ [Principles and Fundamentals in Law - Theory and Prax. Conference Proceedings Olomouc Debates of Young Lawyers], (Praha, Leges, 2010).

7. Jan Pinz, Právní principy, zásady a legis ratio [Legal Principles, Fundamentals and Ratio Legis], 110, in Právni principy - kolokvium [Legal Principles - Colloquium] (Pelhřimov, Vydavatelství 999, 1999).

8. Jana Dostálová, Jaromír Harvánek, Právní principy a procesní zásady. [Legal Principles and Procedural Fundamentals], 106, in Právni principy - kolokvium [Legal Principles - Colloquium] (Pelhřimov, Vydavatelství 999, 1999).

9. Jan Pinz, supra n. 7, at 114-115.

10. For more details see Vladimír Babčák supra n. 4, at 423 or Martin Vernarský, Procesné zásady dañového konania. 2. aktualizované a doplnené vydanie [Procedural Principles of Tax Proceedings. 2nd Actualized and Amended Issue], 20-24, (Košice, Univerzita Pavla Jozefa Šafárika v Košiciach, 2013).

11. Adrián Popovič, The Rule of Time-Barred Effect of Passage of Time in Tax Administration in the Slovak Republic, 385, in Tax Codes Concepts in the Countries of Central and Eastern Europe (Bialystok, Temida 2, 2016).

12. Mária Bujňáková, Zásady a princípy daňového konania [Fundamentals and Principles of Tax Proceedings], 11-23, in Zeszyty Naukowe Universytetu Rzeszowskiego: seria prawnicza [Scientific Writings of the University of Rzeszow: Law Series], vol. 91, no. 18 (2016). https://doi.org/10.15584/znurprawo.2016.18.1

13. See Mária Bujňáková, Právne princípy v tvorbe a výklade daňového práva [Legal Principles in Legislation and Application of Tax Law], 282-286, in Právny obzor: teoretický ćasopis pre otázky štátu a práva, vol. 86, no. 3 (2003); Adrián Popovič, Princíp zákonnosti a princíp právnej ochrany v správe daní [The Principle of Legality and the Principle of Legal Protection in Tax Administration], 129-137, in Teória a prax verejnej správy: recenzovaný zbornik prispevkov z vedeckej konferencie doktorandov: 17.2.2016, Košice [Theory and Praxis of Public Administration: Reviewed Book of Proceedings from Scientific Doctoral Conference: Kosice, 17 February 2016], (Košice, Univerzita Pavla Jozefa Šafárika v Košiciach, 2016); Jozef Sábo, Princípy dañového práva a daňová politika štátu - alebo existuje hranica, ktorá sa nesmie prekročit?' [Principles of Tax Law and 
State Tax Policies - or Does a Border Exist Which Must Not Be Crossed?], 376-384, Poñatie a charakter práva: zborník príspevkov z medzinárodnej vedeckej konferencie: 27. február 2014, Bratislava [Idea and Character of Law: Book of Proceedings from International Scientific Doctoral Conference: Bratislava, 27 February 2014] (Bratislava, SAP - Slovak Academic Press, 2014); Miroslav Štrkolec, Zákonnost ako princíp (zásada) daňového konania [Legality as a Tax Procedure Principle], 277-287, in Humanum, vol. 4, no. 1 (2010).

14. Vladimír Babčák, K problematike princípov a zásad daňového konania [On the Issue of Principles and Fundamentals in Tax Procedure], 13-25, in Acta Oeconomica Cassoviensia No 5. (Košice, Podnikovohospodárska fakulta v Košiciach, 2001).

15. See also Anna Románová, Vybrané zásady daňového konania tak, ako ich nepoznali klasické rozprávky [Selected Principles of Tax Procedures, as they Are not Known in Classical Fairy Tales], 25-32, in Acta Iuridica Olomoucensia (vol. 7, no. 1, 2012); Anna Románová, Karolína Červená, Nová úprava zásady skutočného obsahu právneho úkonu v daňovom poriadku [The New Regulation of the Principle of Material Content of Legal Act in the Tax Ordinance], 198-203, in Marketing, manažment, obchod a sociálne aspekty podnikania: zbornik recenzovaných príspevkov z 2. ročnika medzinárodnej vedeckej konferencie: 23. - 24. október 2014, Kosice [Marketing, Management, Business and Social Aspects of Enterprises: Reviewed Book of Proceedings from the 2. Season of International Scientific Conference: Kosice, 23-24 October 2014] (Košice, Ekonomická univerzita v Bratislave - Podnikovohospodárska fakulta so sídlom v Košiciach, 2014).

16. See Karin Prievozníková, Implementácia zákazu zneužitia práva do daňového poriadku [Implementation of the Prohibition of Abuse of Rights in the Tax Ordinance], 161-168, in Daňovéprávo vs. dañovépodvody a daňové uniky: nekonferenčný zbornik vedeckých prác. II. diel [Tax Law vs. Tax Fraud and Tax Evasion: Non-conference Book of Scientific Work. II. part.] (Košice, Univerzita Pavla Jozefa Šafárika v Košiciach, 2015).

17. See Adrián Popovič, The Rule of Time-Barred Effect of Passage of Time in the Tax Administration of the Slovak Republic, 383-397, in Tax Codes Concepts in the Countries of Central and Eastern Europe (Bialystok, Temida 2, 2016).

18. Vladimír Babčák, Slovenské daňové právo [Slovak Tax Law], 25 (Bratislava, EPOS, 2012).

19. Babčák, supra n. 4, at 24.

20. Judgment of the Supreme Court of the Slovak Republic of 28 February 2005, sp. zn. 2 Sž-o-KS 56/04.

21. Sergej Kohout, Vecné plnenie v daňovom konaní [Material Fulfillment in Tax Procedure], 42-43, in Justičná revue, vol. 48, no. 2 (1996).

22. See Babčák, supra n. 4, 66-68. 